\title{
Education Value Chain Model for Examination, Grading, and Evaluation Process in Higher Education based on Blockchain Technology
}

\author{
Meyliana ${ }^{1, *}$, Yakob Utama Chandra ${ }^{1}$, Cadelina Cassandra ${ }^{1}$, Surjandy $^{1}$, Erick Fernando ${ }^{1}$, Henry Antonius Eka Widjaja ${ }^{1}$, Harjanto Prabowo $^{2}$ \\ ${ }^{I}$ Information Systems Department, School of Information Systems, Bina Nusantara University, Jakarta, 11480, Indonesia \\ ${ }^{2}$ Computer Science Department, Bina Nusantara University, Jakarta, 11480, Indonesia
}

\begin{tabular}{l} 
A R T I C L E I N F O \\
\hline Article history: \\
Received: 20 November, 2020 \\
Accepted: 08 December, 2020 \\
Online: 28 December, 2020 \\
\hline Keywords: \\
Blockchain \\
Examination \\
Evaluation \\
Grading \\
Higher education \\
Student
\end{tabular}

\begin{tabular}{l} 
A B S T R A C T \\
\hline Blockchain is a solution to improve data integrity and minimize data manipulation. \\
Blockchain technology can be used in student examination management in universities. The \\
process of managing student examination produces some information that can be stored in \\
a blockchain database such as information about the lecturer as the exam creator, exam \\
proctor, student attendance, student exam scores, and the student study continuity status. \\
Blockchain technology ensures student data is valid and reliable, therefore, the company's \\
or organizational trust the teaching and learning process in higher education. This \\
research was conducted using a qualitative approach, which is user center design (UCD) \\
the goal is building a blockchain technology model that can be used by universities in the \\
process of managing student examination, grading, and evaluation. This process will be \\
repeated every semester until students graduate from the university. The propose of this \\
research is to create a business process model based on blockchain technology that can \\
improve data integrity in universities.
\end{tabular}

\section{Introduction}

In teaching and learning process in higher education, students will pass through midterm exams, final exams, lab exams, and certification exams [1]. This examination is carried out to measure the student comprehension during the teaching and learning process. Lecturer can also measure how far learning objectives achieved during the process [2].

After examination, students will get the score according to the criteria determined by the department or university. All grade will be recorded in Student Academic Transcript. This Academic Transcript is a reference for company to hired new graduate working in their company [3]. The company will filter the grade and choose the relevant position according to the student ability [4].

Valid and reliable grade will increase the company or organizational confidence and trust in the teaching and learning process that occurs in higher education [5]. However, in 2019 until now, there have been several cases of diploma certificate forgery. As the impact, the company or organization doubts about

*Corresponding Author: Meyliana, Meyliana@binus.edu the data originality stated on the academic transcript and they need to crosscheck back the data to the university [6].

This is challenge by the university to keep the data integrity and security from any manipulation. According to the case happen in 2019, employee working in the company can also be a threat who manipulate the data [7].

This problem requires universities to updates the technology used, especially those concerning the data integrity and security. Blockchain technology is immutable, unchangeable. It also peer to peer, distributed (transparent), validated, and secured, which are very suitable for solving data integrity and security issues [7], [8].

One of the main processes in producing student grades is student examinations management process. This process has several sub processes, they are examination creation process, exam proctor attendance recapitulation, Student attendance recapitulation, the grading process (collecting exam answer and grading from lecture, and the evaluation process (to determine the student status for next semester).

All of the processes will produce data and information in academic transcript which are very important for students, the 
validity of data and information is a top priority for universities to For this reason, blockchain solutions are needed in managing student value data [9].

Based on the phenomena, the research question for this research is how to build an education value chain model in student exam management process based on blockchain technology in universities? The goal is to build an education value chain model for exam management process to ensure the data integrity.

\section{Literature Review}

\subsection{Education Value Chain}

This section discusses the Education value chain in general, starting from prospective students applying to the university, pass the test, and accepted as students. Students follow two types of activities during their study at higher education, they are intracurricular and extra-curricular activities.

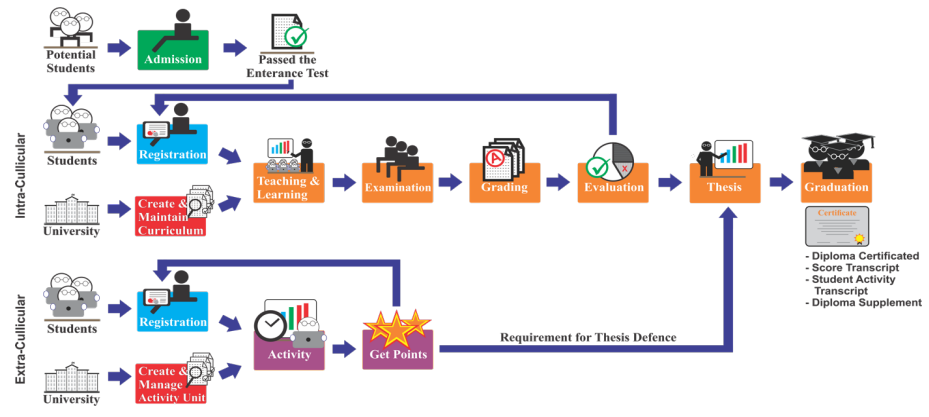

Figure 1: Education Value Chain

The intra-curricular activity starts from course registration for each semester. Then students will follow the teaching and learning process, students will take mid and final exams in each semester. For each exam, lecturer will give the score to students. Based on the results, students will be evaluated by the department and academic advisory unit so student status can be known every semester. In the final semester, students will take a final project or thesis, and thesis defense will be carried out at the end. Apart from following intra-curricular activities, students also take part in extra-curricular activities. Students will register to student organizations and participate in the organization activity. As a result of participating in the activities, students will get points. The points are collected into Student Activity Transcript (SAT). This SAT points is a pre-requisite for thesis defense [7].

\subsection{Examination}

In general, in one semester there are two exams, mid exam and final exam. With examination, the department or university can find out how far students can understand the overall material delivered and how far the learning objectives achieved. In addition, exam answers can provide feedback for lecturers, departments, and universities [10].

\subsection{Grading}

After the student takes the exam, the lecturer will give a score in accordance with the assessment measurement set by the university. Grading is the starting point for students to get a cumulative achievement index measured from the cognitive side of students during the teaching and learning process. Assessment may vary according to the type of exam being performed. The theory exam can be assessed based on the answers written by students. Oral exams or presentations are assessed directly based on the results of student presentations. Meanwhile, practical lab exams can be assessed based on the results of the practicum work made [11].

\subsection{Evaluation of Study Progress}

After students finish their semester, the department and academic supervisor unit will evaluate the learning progress. If students get the satisfactory results, the student may be got appreciation. However, if the evaluation process result is not good, Student will follow various coaching and guidance determined based on student cases and discussions between departments and student advisory units. On the other hand, if students get poor grades and less motivation, then the department and student advisory unit will try to provide solutions according to student interests [12].

\subsection{Blockchain in Education}

Blockchain research in education can provide new insights to education practitioners. Blockchain technology can be used to improve data integrity to minimize crimes such as diploma certificate forgery. In addition, previous research related to blockchain implementation is the application of smart contracts to business processes in universities [9][13].

\section{Research Methodology}

Research methodhology used in this research is user-centered design (UCD) [14]. In UCD methodology, research begins with an understanding of the context of use, at this stage a literature study is carried out related to the implementation of blockchain technology in universities. The next stage is to specify user requirements by conducting observations, interviews, and focus group discussions (FGD) to determine the teaching and learning process, especially in examination, grading, and evaluation.

Then a design solution was carried out by creating an education value chain model for the examination, grading and evaluation processes that apply to universities based on blockchain technology. At this stage, it is also described in detail the business processes and identify which activities need to store data and information to the blockchain database. The next stage is evaluate the requirements, FGD is conducted to see whether the model can be accepted and implemented in each university. This evaluation becomes input for validation on the design solution, specify user requirements and understand context of use. If there are things that are still not suitable, then it becomes feedback for the improvement of each stage in this research methodology.

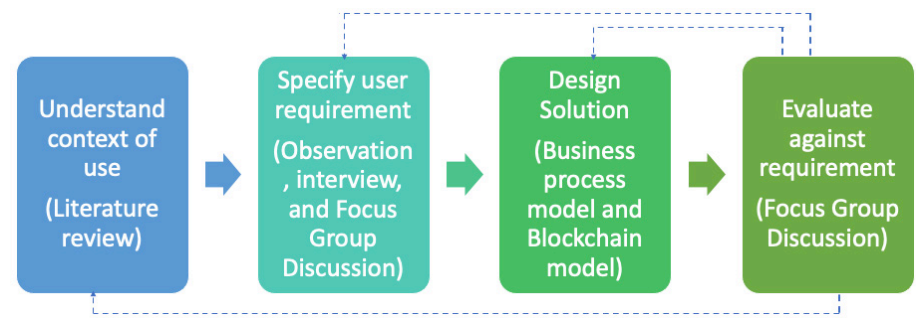

Figure 2: Research Methodology 


\section{Result and Discussion}

The teaching and learning process in higher education which is discussed in this study is the examination, grading and evaluation process as shown in Figure 3.

These three processes are focused on the process of student examination management and evaluations starting from the preparation, execution, and evaluation of student study. All data generated in this process will be stored in a blockchain database so that universities can guarantee the data they have cannot be manipulated and have a good integrity.

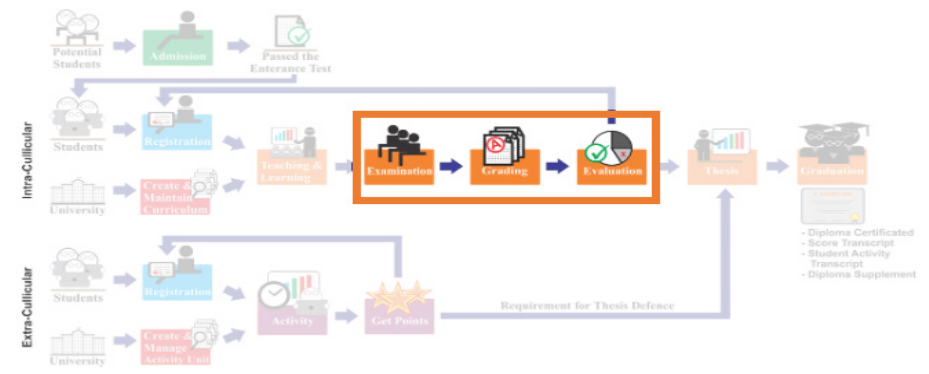

Figure 3: Focus of Research

The examination process begins with exam schedule by the student scheduling department. From the exam schedule, the department will determine the lecturer as the exam question creator. The lecturer will fill out an Exam Agreement Form that contains the topic of the questions and the learning outcomes that will be achieved by students after completing the exam. This form is filled to get the standardized exam questions and approval from the department. The data of the lecturer will be recorded on the blockchain database for honorarium.

The questions that have been completed will be examined by the department and given to the academic operations section to be distributed according to the exam schedule to students.

The exam scheduling section will also schedule the lecturers as exam proctor and the attendance realization data will be stored in a blockchain database as proof of payment of exam proctor fees.

Students take the exam twice per semester (mid exam and final exam). For a practicum course, students take a practicum exam. In each exam, the attendance will be recorded, and this data is stored in a blockchain database as proof of student attendance in the exam.

If the student is absent or cannot attend the exam, student can apply for a make-up exam in accordance with the applicable terms and conditions.

The exam answers are collected by the exam proctor to academic operations section. The academic operational section will validate the answer and distribute it to the lecturer. The lecturer will check the answers and gives score to each student. The score is entered by the lecturer through the system and will be validated by the department in the score judiciary. Student scores consist of several components, such as assignment scores, mid-test scores and final exam scores. This score is stored in the blockchain database. Lecturers will receive the examiner's honorarium according to the number of exam files corrected and proof of payment of this honorarium is stored in the blockchain database.
All grades entered in one semester will be evaluated by the academic supervisor and department. The results of the evaluation will determine the status of students in the continuity of the studies. The status will be stored in the blockchain database.

Figure 4 shows the transactions illustration from the education value chain model for the examination, grading and evaluation processes based on blockchain technology. Users who play a role in the examination, grading, and evaluation processes are students, lecturers, academic operations, scheduling units, student advisory units, and faculty / departments.

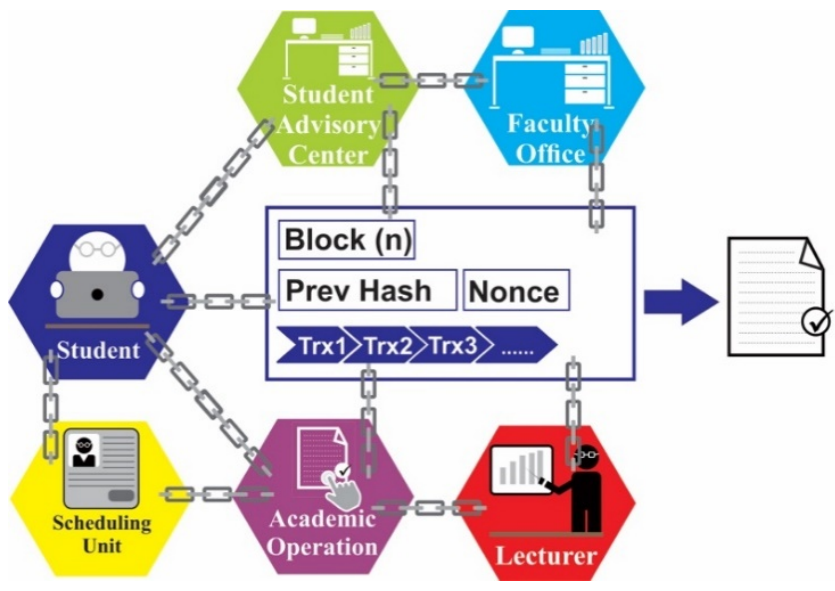

Figure 4: Transaction Illustration of Education Value Chain Model for Examination, Grading, and Evaluation for Higher Education based on Blockchain Technology

Figure 5 ( $\mathrm{a}$ and $\mathrm{b}$ ) shows the college's business process in teaching and learning activities focusing on the examination, grading, and evaluation processes. From the business process described in Figure 4 above, the data storage in the blockchain database is important in connection to the financial audit and payment process. The data are:

- Record name of lecturer as the exam creator

- This data contains the semester period, lecturer code, course code, class code, exam date, and honorarium amount.

- $\quad$ Record name of Exam Proctor

- This data contains the semester period, lecturer code, course code, class code, exam date, exam room.

- Record the attendance list of students and exam proctor

- This data contains the semester period, lecturer code, course code, class code, exam date, exam room, student code, and the amount of the exam proctor fee.

- $\quad$ Record a score of students and Record the new score.

- This data contains the semester period, course code, class code, exam date, exam room, student code, exam component code, and student scores.

- Record a payment of scoring honorarium to lecturer

- This data contains the semester period, lecturer code, course code, class code, exam date, exam room, number of students and the amount of honorarium

- Record the student's evaluation for each semester

- This data contains the semester period, course code, student code, component code grades, grades, social studies, and GPA 


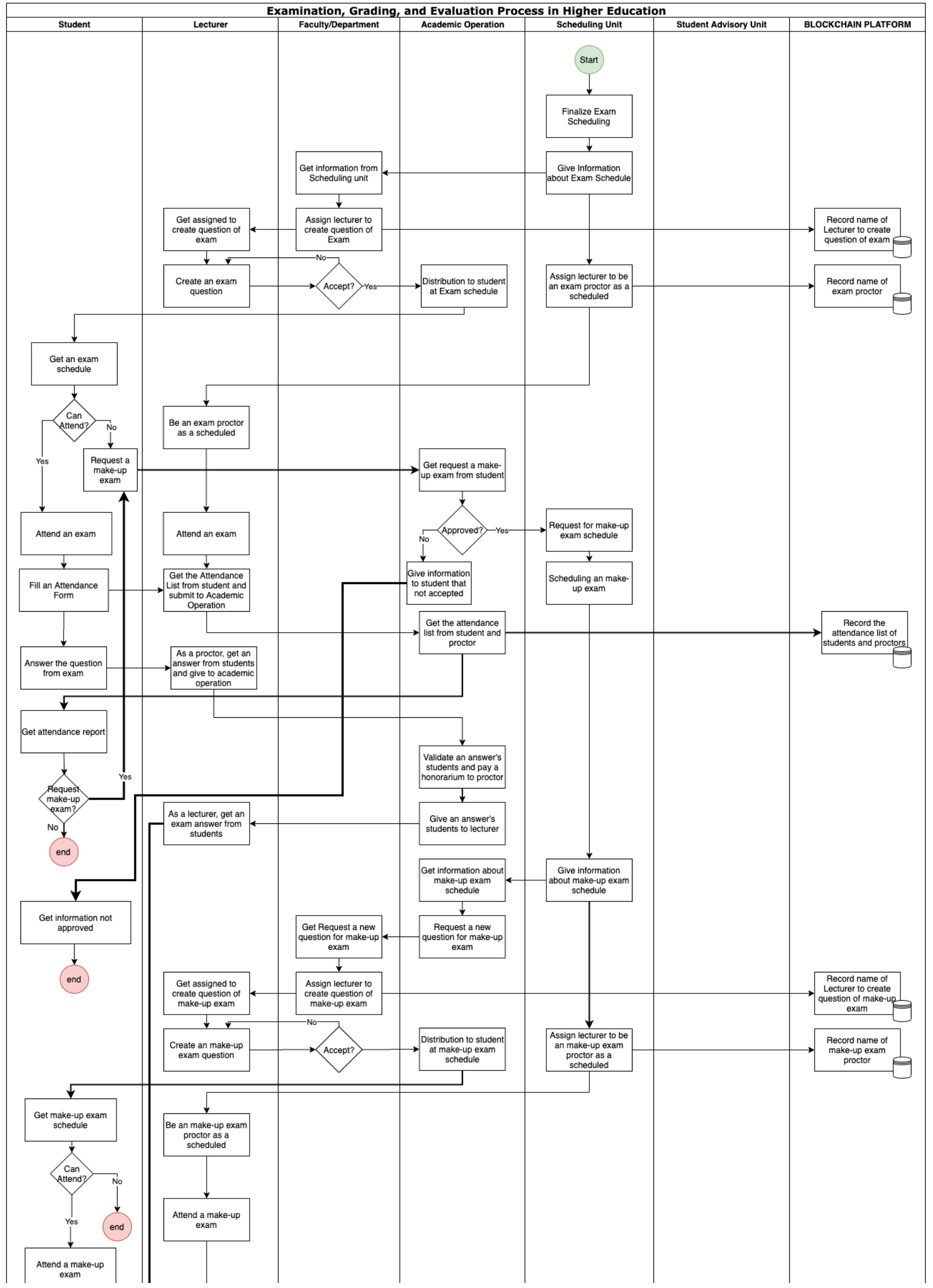




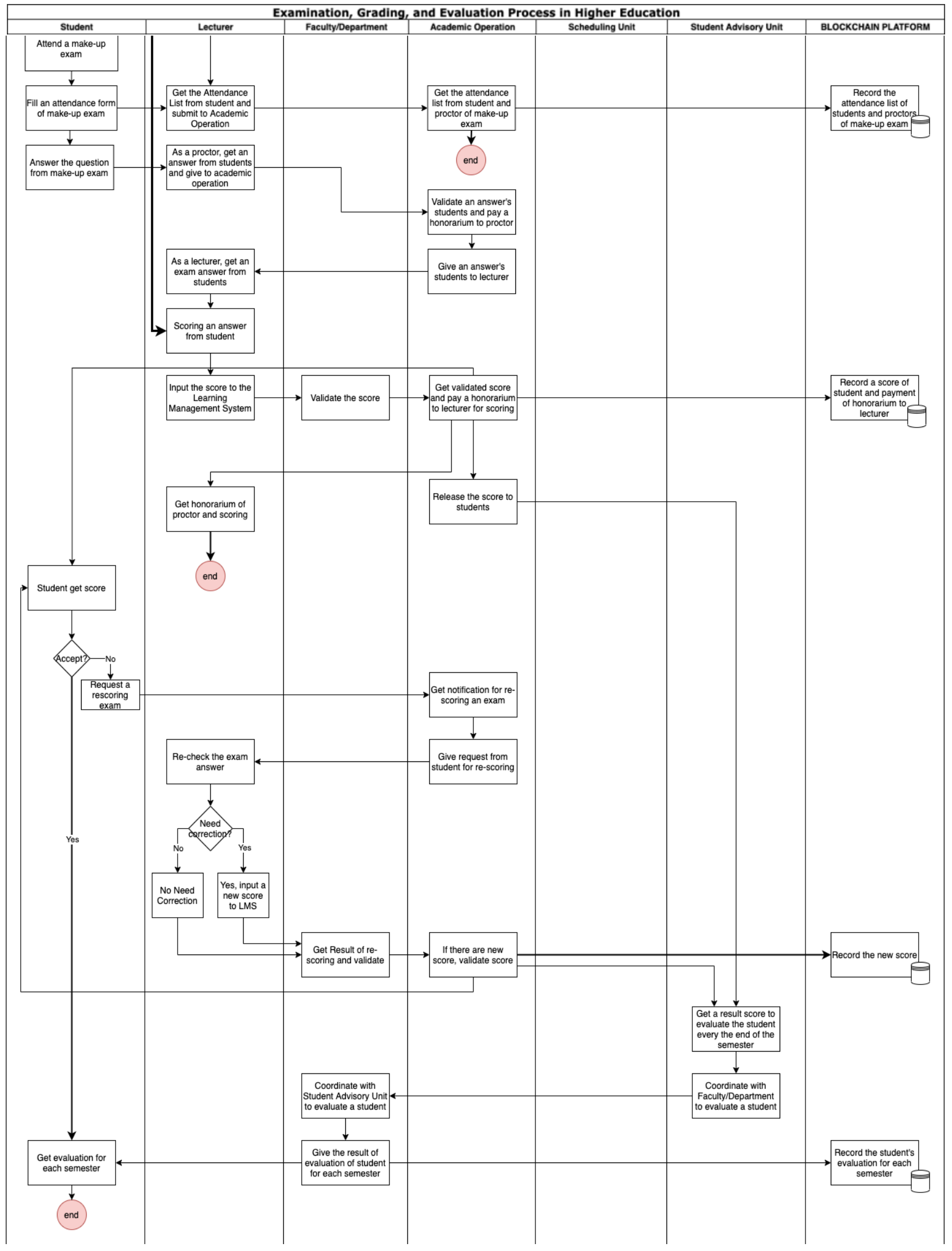

Figure 5: (a) Business Process of of Education Value Chain Model for Examination, Grading, and Evaluation for Higher Education based on Blockchain Technology (b) Business Process of of Education Value Chain Model for Examination, Grading, and Evaluation for Higher Education based on Blockchain Technology 


\section{Conclusions}

By using blockchain technology, it can be concluded that data integrity will be guaranteed, and data storage is more secure because the data has been validated and cannot be changed. Data changes can still occur by making new transactions without eliminating previous transactions, for example when students protest the score which causes the previous score to change. The Both scores are stored in the blockchain database.

Following the research methodology, we have conducted a focus group discussion to validate the model that has been made and the results are that all participants agree with this model and they think this study can be easily applied in universities in recording the academic transcript.

The process of examination, grading, and evaluation is very appropriate using blockchain technology, because this process is very crucial and requires data validity to produce the academic transcript for students.

In the current condition of the Covid-19 pandemic, using blockchain technology is more needed because the process input and evaluation are done digitally. With blockchain technology, universities make a digital transformation in the education sector and make education technology more effective, especially during the Covid-19 pandemic.

The limitations of this study are the process of interviewing and focus group discussion using virtual conferencing to get answers from the speakers and there is limited time in digging deeper into the information needed. So it is necessary to do the validity of the resulting model several times. Future research will build an integrated overall model to produce a value chain with data integrity starting from students entering higher education until students graduate and get diplomas, transcripts, diploma companion documents, and student activity transcripts.

\section{Acknowledge}

This study is supported by the Directorate General of Strengthening for Research and Development, Ministry of Research, Technology, and Higher Education, Republic of Indonesia as a part of Penelitian Terapan Unggulan Perguruan Tinggi Research Grant to Bina Nusantara University entitled "Implementasi Blockchain Platform untuk Menciptakan "Good Governance" pada Perguruan Tinggi" or "The Implementation of Blockchain Platform to Create "Good Governance" in Higher Education" with contract number: 12/AKM/PNT/2019 and contract date: 27 March 2019.

\section{Conflict of Interest}

The authors declare no conflict of interest.

\section{References}

[1] M.M.A. Getso, Z. Johari, "the Blockchain Revolution and Higher Eucation," International Journal of Information Systems and Engineering, 5(1), 57-65, 2017, doi:10.24924/ijise/2017.04/v5.iss1/57.65.

[2] R. Wuthisatian, "Student exam performance in different proctored environments: Evidence from an online economics course," International Review of Economics Education, 35(August), 100196, 2020, doi:10.1016/j.iree.2020.100196.

[3] Z. Wu, T. He, C. Mao, C. Huang, "Exam paper generation based on performance prediction of student group," Information Sciences, 532, 72-90, 2020, doi:10.1016/j.ins.2020.04.043.

[4] M. Apte, A. Bhave-gudipudi, "ScienceDirect Cooperative Learning techniques to bridge gaps in academia and corporate," Procedia Computer Science, 172(2019), 289-295, 2020, doi:10.1016/j.procs.2020.05.046.

[5] A. Herrarte, R. Llorente-heras, A. Herrarte, R. Llorente-heras, "Competencies, occupational status, and earnings among European university graduates," 2017, doi:10.1016/j.econedurev.2017.10.006.

[6] Meyliana, Y.U. Chandra, C. Cassandra, Surjandy, E. Fernando, A.E. Widjaja, H. Prabowo, "A Proposed Model of Secure Academic Transcript Records with Blockchain Technology in Higher Education," (Conrist 2019), 172-177, 2020, doi:10.5220/0009907401720177.

[7] M. Meyliana, Y.U. Chandra, C. Cassandra, S. Surjandy, H.A. Eka Widjaja, E. Fernando, H. Prabowo, C. Joseph, "DEFYING THE CERTIFICATION DIPLOMA FORGERY WITH BLOCKCHAIN PLATFORM: A PROPOSED MODEL," in Proceedings of the International Conferences ICT, Society, and Human Beings 2019; Connected Smart Cities 2019; and Web Based Communities and Social Media 2019, IADIS Press: 63-71, 2019, doi:10.33965/ict2019_201908L008.

[8] S. Singh, N. Singh, "Blockchain: Future of financial and cyber security," Proceedings of the 2016 2nd International Conference on Contemporary Computing and Informatics, IC3I 2016, 463-467, 2016, doi:10.1109/IC3I.2016.7918009.

[9] M. Turkanovic, M. Holbl, K. Kosic, M. Hericko, A. Kamisalic, "EduCTX: A blockchain-based higher education credit platform," IEEE Access, 6, 2018, doi:10.1109/ACCESS.2018.2789929.

[10] L.M. Daniels, M.J. Gierl, "The impact of immediate test score reporting on university students ' achievement emotions in the context of computer-based multiple- choice exams," Learning and Instruction, 2017, doi:10.1016/j.learninstruc.2017.04.001.

[11] I. Cornelisz, M. Meeter, C. van Klaveren, "Educational equity and teacher discretion effects in high stake exams," Economics of Education Review, 73(November 2018), 101908, 2019, doi:10.1016/j.econedurev.2019.07.002.

[12] H. Liao, J. Hitchcock, Reported Credibility Techniques in Higher Education Evaluation Studies that use Qualitative Methods: A Research Synthesis, Elsevier Ltd, 2018, doi:10.1016/j.evalprogplan.2018.03.005.

[13] R. Bdiwi, C. de Runz, S. Faiz, A.A. Cherif, "Towards a New Ubiquitous Learning Environment Based on Blockchain Technology," 2017 IEEE 17th International Conference on Advanced Learning Technologies (ICALT), 101-102, 2017, doi:10.1109/ICALT.2017.37.

[14] What is User Centered Design? | Interaction Design Foundation (IxDF), Nov. 2020 